\title{
Hydrologic Investigation of Powell Marsh and its Relation to Dead Pike Lake, Vilas County, Wisconsin
}

Water-Resources Investigations Report 02-4034
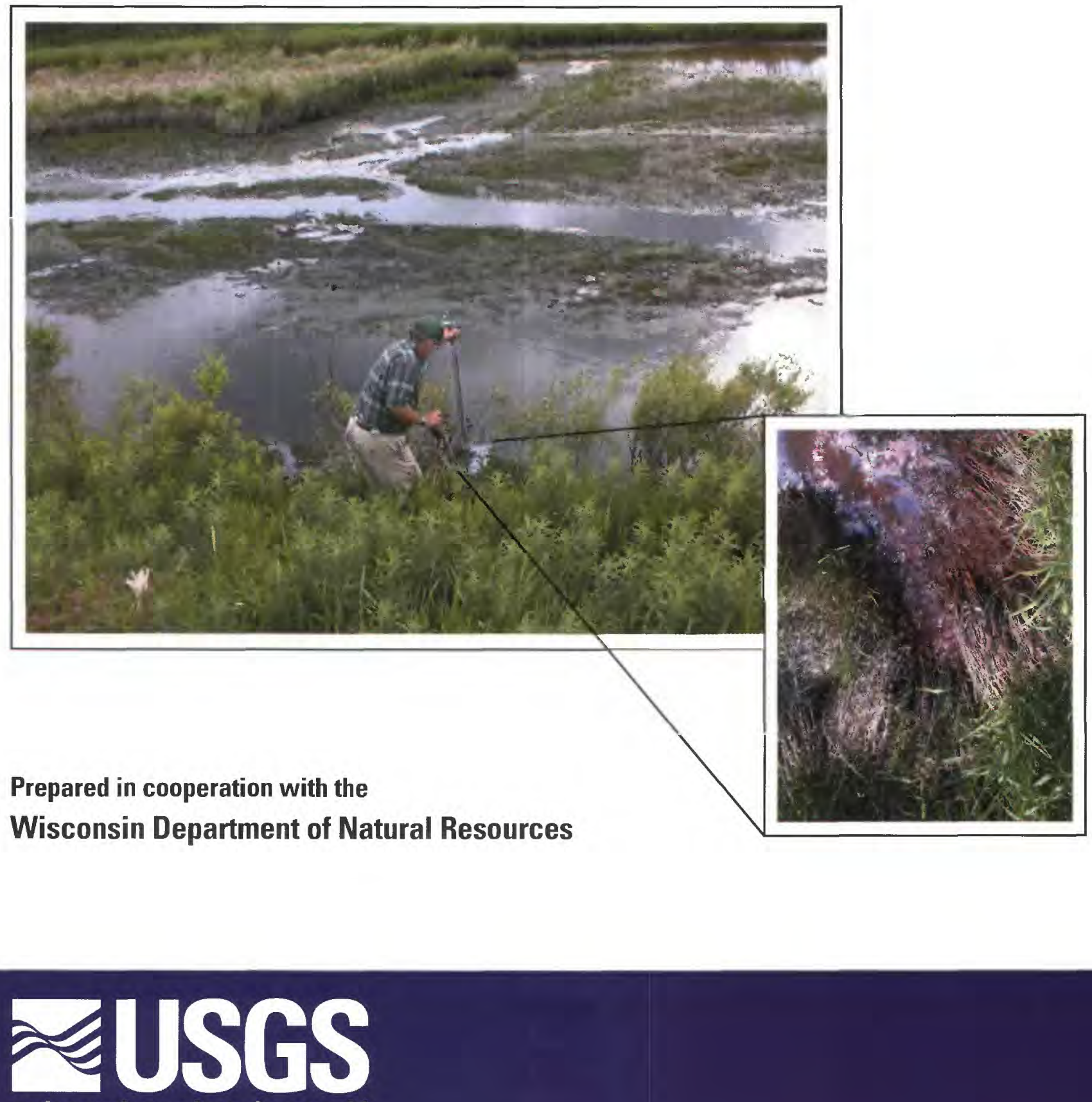



\section{Hydrologic Investigation of Powell Marsh and its Relation to Dead Pike Lake, Vilas County, Wisconsin}

By James T. Krohelski, William J. Rose, and Randall J. Hunt

U.S. GEOLOGICAL SURVEY

Water-Resources Investigations Report 02-4034

Prepared in cooperation with the

Wisconsin Department of Natural Resources

Middleton, Wisconsin 2002

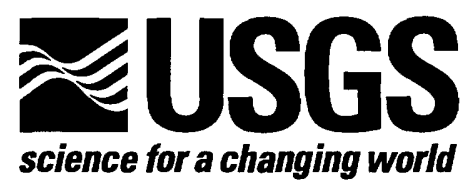




\title{
U.S. DEPARTMENT OF THE INTERIOR \\ Gale A. Norton, Secretary
}

\author{
U.S. GEOLOGICAL SURVEY \\ Charles G. Groat, Director
}

The use of firm, trade, and brand names in this report is for identification purposes only and does not constitute endorsement by the U.S. Government.

District Chief

U.S. Geological Survey

8505 Research Way

Middleton, WI 53562-3586
U.S. Geological Survey

Branch of Information Services

Box 25286

Denver, CO 80225-0286 


\section{CONTENTS}

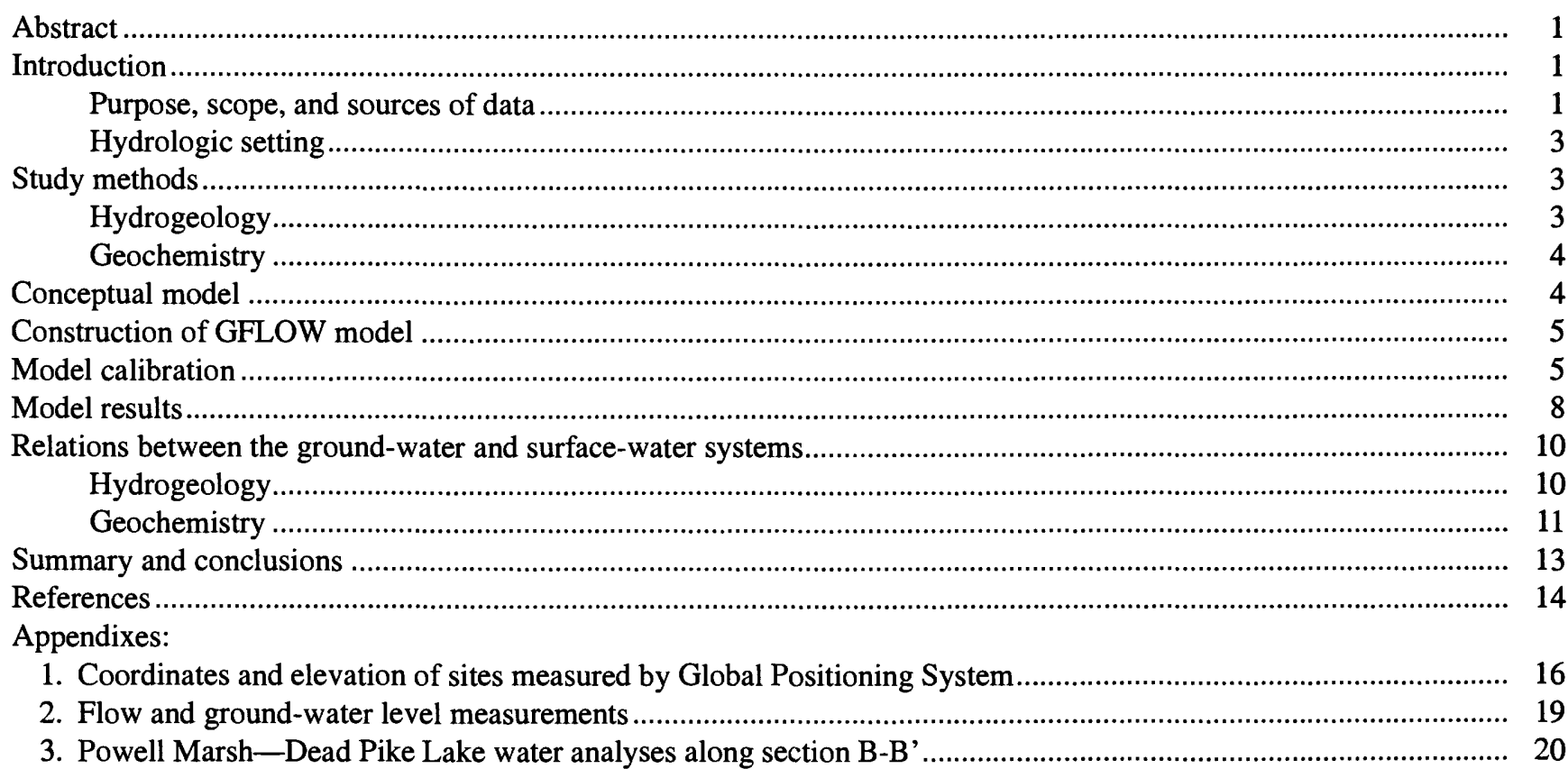

\section{FIGURES}

1. Map showing location of Powell Marsh and Dead Pike Lake, Vilas County, Wisconsin........................................ 2

2. Section showing conceptual model of the hydrologic system in the vicinity of Dead Pike Lake ............................. 4

3. Simulated hydrologic features with analytic elements and location of calibration targets for the ground-water-

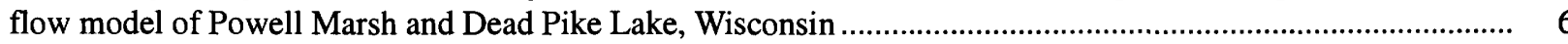

4-5. Graphs showing:

4. Measured and simulated head for the ground-water-flow model of Powell Marsh and Dead Pike Lake,

Wisconsin

5. Measured and simulated flux for the ground-water-flow model of Powell Marsh and Dead Pike Lake,

Wisconsin

6. Simulated water-table elevation and selected path lines for (A) calibration and (B) without Powell Marsh structures, Vilas County, Wisconsin

7-10. Graphs showing:

7. West to east section, B-B', showing the position of the water table and direction of ground-water flow ........... 10

8. Comparison of iron concentrations in 0.45 and 0.1 micron-filtered water samples ......................................... 11

9. Comparison of dissolved organic carbon concentrations to iron in 0.45 micron-filtered samples .................... 12

10. Relation of iron concentration in 0.45 micron-filtered samples to redox potential ........................................... 13 


\section{CONVERSION FACTORS, VERTICAL DATUM, AND ABBREVIATIONS}

\begin{tabular}{|c|c|c|}
\hline Multiply & By & To Obtain \\
\hline \multicolumn{3}{|c|}{ Length } \\
\hline inch (in) & 25.4 & millimeter \\
\hline foot $(\mathrm{ft})$ & 0.3048 & meter \\
\hline mile (mi) & 1.609 & kilometer \\
\hline \multicolumn{3}{|c|}{ Area } \\
\hline acre $(\mathrm{A})$ & 0.4047 & hectare \\
\hline square foot $\left(\mathrm{ft}^{2}\right)$ & 0.09290 & square meter \\
\hline square mile $\left(\mathrm{mi}^{2}\right)$ & 2.590 & square kilometer \\
\hline \multicolumn{3}{|c|}{ Volume } \\
\hline cubic foot $\left(\mathrm{ft}^{3}\right)$ & 0.02832 & cubic meter \\
\hline \multicolumn{3}{|c|}{ Hydraulic Conductivity* } \\
\hline foot per day (ft/d) & 0.3048 & meter per day \\
\hline
\end{tabular}

Sea level: In this report, "sea level" refers to the National Geodetic Vertical Datum of 1929 (NGVD of 1929)-a geodetic datum derived from a general adjustment of the first-order level nets of both the United States and Canada, formerly called Sea Level Datum of 1929.

*Hydraulic conductivity: The standard unit for hydraulic conductivity is cubic foot per day per square foot of aquifer cross-sectional area $\left(\mathrm{ft}^{3} / \mathrm{d}\right) / \mathrm{ft}^{3}$. In this report, the mathematically reduced form, feet per day (f/d), is used for convenience.

\section{Other abbreviations:}

$\begin{array}{ll}\mathrm{ft}^{3} / \mathrm{s} & \text { cubic feet per second } \\ \mathrm{gpm} & \text { gallons per minute } \\ \mathrm{mg} / \mathrm{L} & \text { milligrams per liter } \\ \mathrm{in} / \mathrm{yr} & \text { inches per year }\end{array}$

The stratigraphic nomenclature used in this report is that of the Wisconsin Geological and Natural History Survey and does not necessarily follow usage of the U. S. Geological Survey. 


\title{
Hydrologic Investigation of Powell Marsh and its Relation to Dead Pike Lake, Vilas County, Wisconsin
}

\author{
By James T. Krohelski, William J. Rose, and Randall J. Hunt
}

\section{Abstract}

An analytic element ground-water-flow model was constructed to help understand the ground- and surface-water hydrology in the vicinity of Dead Pike Lake and Powell Marsh, Vilas County, Wisconsin. The model was used to simulate the effect of removing Powell Marsh control structures (ditches and Vista Pond) on the hydrology of Dead Pike Lake. Measurements and model simulation results show that ground water in the vicinity of Powell Marsh moves to the northwest and west. If Powell Marsh structures are removed from the simulation, it does not affect the general direction of ground-water flow nor the total flow to Dead Pike Lake. Without the simulated structures, slightly more ground-water flow enters Dead Pike Lake and slightly less surface-water flows at the Dead Pike Lake inlet than with the simulated structures.

Ground-water levels measured in piezometers installed along a flow path indicated that ground-water flow primarily is horizontal in the marsh and moves upward in the vicinity of a ditch where it discharges. Flow from Vista Pond is downward to the ground-water system but eventually also discharges upward to the ditches. Based on analyses of water samples from piezometers, the ditch, and Vista Pond, it was shown that dissolved iron is transported in the ground water. When ground water is discharged, iron and manganese react with dissolved oxygen, then precipitates, and forms the oxyhydroxide floc present in the Powell Marsh ditches. The processes involved in the transport and floc formation are not unique to the ditches, but are an expected outcome where discharging ground water and oxygenated surface water meet. Therefore, although floc formed in the ditches would no longer be available for transport if ditches were removed, it is likely that the floc formation would be redirected to the near-shore areas of Dead Pike Lake where increased groundwater discharge is expected.

\section{INTRODUCTION}

Dead Pike Lake and Powell Marsh are located in western Vilas County, Wis. (fig. 1). Local residents are concerned that iron floc from Powell Marsh ditches is damaging the aesthetic quality of their lake. The U.S. Geological Survey (USGS) in cooperation with the Wisconsin Department of Natural Resources (WDNR) began a study in June 2000 to evaluate the effects of Powell Marsh on the hydrology of Dead Pike Lake and to determine the source of iron floc and the potential for transport from Powell Marsh to Dead Pike Lake.

\section{Purpose, Scope, and Sources of Data}

This report describes the hydrologic relation between Powell Marsh and Dead Pike Lake, and characterizes the distribution of iron (Fe) and manganese $(\mathrm{Mn})$ in the hydrologic system. Also, the processes responsible for iron transport at various points in the hydrologic system including Vista Pond, marsh, aquifer, ditch, and lake are described. Finally, the effects of altering the ditch system conveying the iron floc to Dead Pike Lake are summarized.

Available geologic and hydrologic data used during this study consisted of interpretive geologic maps presented by Attig (1985), and measured hydraulic conductivity, ground-water levels and contour maps of the water table and depth to rock by Patterson (1989) and Batten and Lidwin (1996). These data form the basis for development of a ground-water-flow model by providing estimates of saturated thickness, the hydraulic properties of the shallow aquifer, and estimates of watertable elevation. These previous studies (Patterson, 1989; Batten and Lidwin, 1996) reported that extremely 


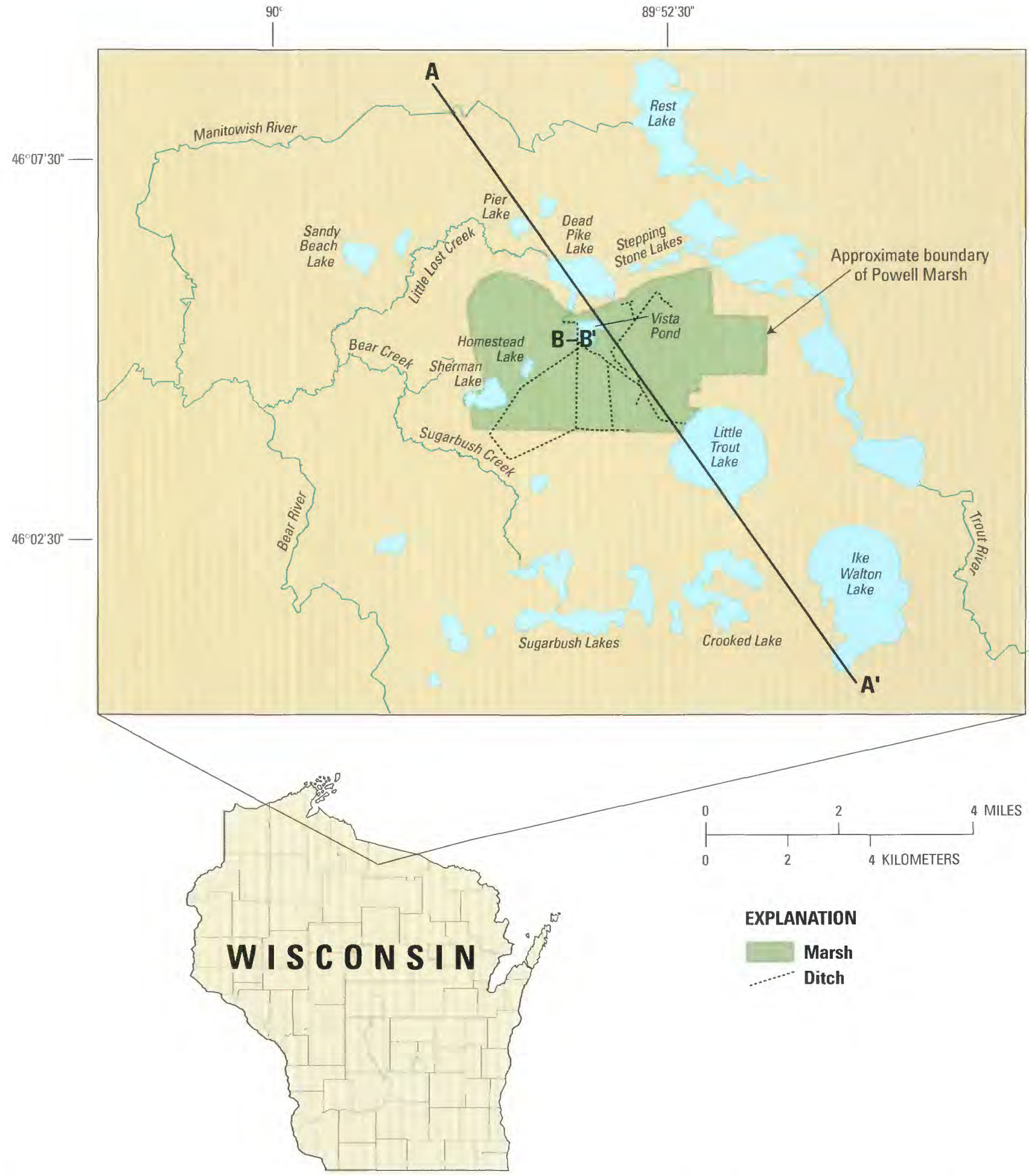

Figure 1. Location of Powell Marsh and Dead Pike Lake, Vilas County, Wisconsin. (A-A' section shown in figure 2; B-B' section shown in figure 7.) 
high iron concentrations (greater than $20 \mathrm{mg} / \mathrm{L}$ ) could be present in the sand-and-gravel sediment in the vicinity of Powell Marsh.

In addition to the available data, field data were collected for the study. A Global Positioning System (GPS) was used to locate and determine elevations of surface-water features, such as streams and lakes throughout the study area and above and below control structures at Powell Marsh. Elevations and site locations of lakes, streams, control structures, and piezometers were measured (Michael T. Anderson, Wisconsin Department of Natural Resources, written commun., 2000). The coordinates and elevations of the sites measured by GPS are listed in appendix 1.

Piezometers, some nested, were installed along a west to east section in Powell Marsh and used to determine the direction of ground-water flow, the relation between the ground-water system, Powell Marsh ditches, and Vista Pond, and to obtain water samples for analyses of dissolved organic carbon (DOC), iron and manganese. Surface-water samples were collected from the main ditch and Vista Pond for DOC, iron, and manganese. Streamflow measurements were made at five sites during the study. Some of the ground-water-level measurements and the streamflow measurements were used in model calibration. The ground-water-level and streamflow measurements are listed in appendix 2.

\section{Hydrologic Setting}

Dead Pike Lake is a 297-acre drainage lake (fig. 1). An inlet flowing to the south side of Dead Pike Lake drains a portion of Powell Marsh. The marsh consists of an extensive system of drainage ditches constructed in the 1950s, some of which drain into the Dead Pike Lake inlet. Sand-and-gravel deposits of the Copper Falls Formation (Pleistocene age) are present throughout the area. These deposits range in thickness from 100 to $200 \mathrm{ft}$ (Attig, 1985). In low-lying areas, 1 to 5 feet of peat overlie the sand and gravel. Reported values of horizontal hydraulic conductivity range from about 1 to $50 \mathrm{ft} / \mathrm{d}$ based on slug tests and $950 \mathrm{ft} / \mathrm{d}$ based on a multiwell aquifer test (Patterson, 1989; Batten and Lidwin, 1996). An aquifer test generally integrates a much larger volume of aquifer compared to a slug test and often yields higher and more representative values of hydraulic conductivity (Bradbury and Muldoon, 1990).

\section{STUDY METHODS}

Methods used to understand the hydrogeology and geochemistry of the study area include development of a ground-water-flow model and analysis of ground water and surface water along a flow path. These methods are described in the following section.

\section{Hydrogeology}

An analytic element ground-water-flow model, using the computer program GFLOW (Haitjema, 1995), was constructed to simulate the shallow ground-water system and its interaction with surface-water features. A complete description of analytic elements is beyond the scope of this report; a brief description is given below. The reader is referred to Strack (1989) and Haitjema (1995) for detailed discussions of this method.

Unlike most modeling methods, the analytic element method assumes an infinite aquifer and does not use a grid or involve interpolation between grid cells. To construct an analytic element model, features important to ground-water flow and surface-water features are entered as mathematical elements or strings of elements. Each element is represented by a mathematical equation. The effects of these individual solutions are superposed or added together to arrive at a solution for the larger ground-water-flow system. Unlike finite-difference modeling where the solution is calculated only at grid nodes, with analytic-element modeling, heads and flows can be computed anywhere in the model domain without nodal averaging. The GFLOW model used here is an areal model and the analytic elements are two-dimensional and only can simulate steady-state conditions (that is, heads do not vary with time). The analytic element method (Strack, 1989; Haitjema, 1995 ) and the comparison of analytic element to finitedifference numerical model techniques (Hunt and Krohelski, 1996: Hunt and others 1998) have been discussed by others.

The GFLOW model was calibrated by trial-anderror; that is, by varying hydraulic conductivity and stream resistance until there was a reasonable match between measured and simulated ground-water levels (heads) and streamflows. 


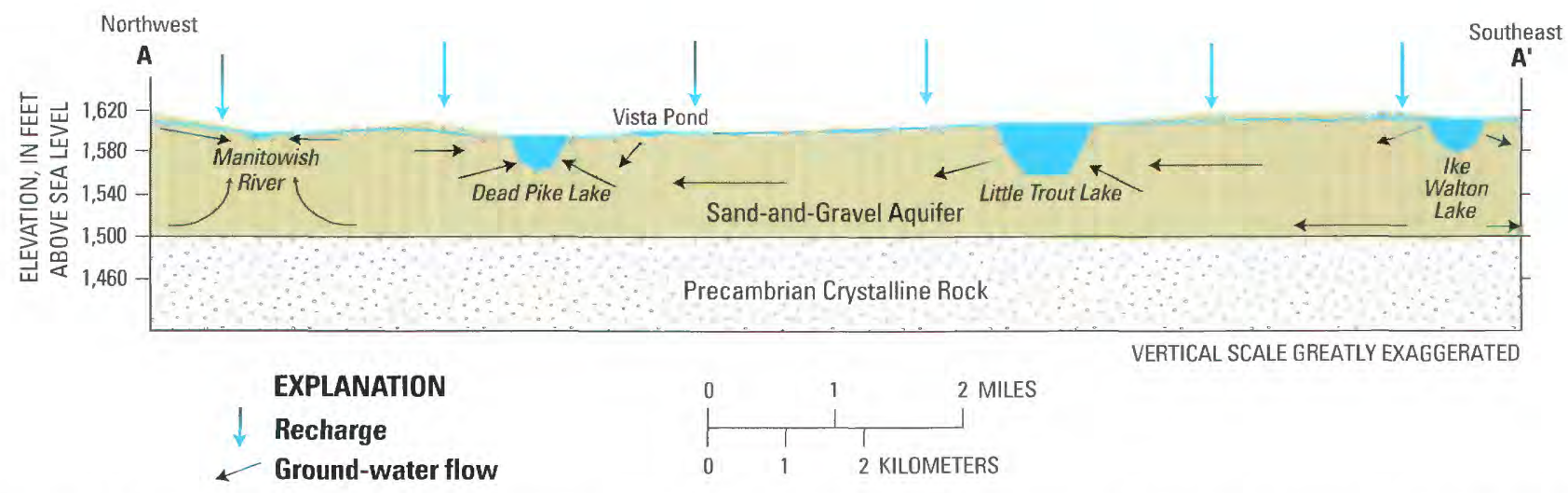

Figure 2. Conceptual model of the hydrologic system in the vicinity of Dead Pike Lake. (Line of section is shown in figure 1.)

\section{Geochemistry}

Ground and surface waters were sampled and analyzed in the field for $\mathrm{pH}$, temperature, specific conductance, redox potential (Eh) and dissolved oxygen (field parameters), and in the laboratory for iron. manganese. and DOC. Field parameters were sampled and measured by pumping the water through a flow-through chamber enclosing the multi-parameter meter sensors. Two sets of samples were taken, one filtered through 0.45 micron filters and one filtered through 0.1 micron filters to assess the potential of colloidal transport. Ground-water samples were collected using a peristaltic pump and an in-line filter. Surface-water samples from Vista Pond and the main ditch were "grabbed" near shore using a 5-gallon pail. Because Vista Pond and the main ditch are shallow and therefore well mixed. the "grab" samples are representative of these surfacewater bodies. The surface-water samples then were filtered using the in-line apparatus. Field and laboratory analyses of sampled water are listed in appendix 3 .

\section{CONCEPTUAL MODEL}

Prior to construction of the ground-water-flow model, a conceptualization of the system is essential because it forms the framework for model development. The conceptualization reduces the actual flow system into important component parts. This reduction is a necessary simplification of the natural system because inclusion of all of the complexities of the natural system into a computer model is not feasible. Steps in the development of the conceptual model include: (1) defi- nition of aquifers and confining units, (2) identification of sources and sinks of water and, (3) identification and delineation of hydrologic boundaries. A conceptualization in cross section of the shallow ground-water/surface-water system in the vicinity of Dead Pike Lake and Powell Marsh is shown in figure 2. The cross section is based on well drillers' construction reports and information collected as part of other studies (see previous cited reports).

The shallow ground-water system consists of laterally extensive deposits of sand and gravel about $100 \mathrm{ft}$ thick. The underlying bedrock unit (Precambrian crystalline rock) forms the base of the aquifer system and is assumed to be nearly impermeable. Therefore, the model included only the most transmissive upper deposits. The water table in the vicinity of the Powell Marsh and Dead Pike Lake is near the land surface except in areas of high relief or elevation. In these areas, the depth to the water table may be more than $50 \mathrm{ft}$ (Batten and Lidwin, 1996).

Ground water moves from higher to lower potentials (or heads) as indicated by the flow arrows in figure 2 . As a result, ground water generally moves toward and discharges to lower-lying surface-water features and recharges (as indicated by the vertical arrows above the section in figure 2) elsewhere. Recharge is that portion of precipitation that does not evaporate, transpire, or run off, and is the primary water source to the ground-water system.

Dead Pike Lake receives surface water from Powell Marsh by way of an inlet channel and because of its position in the ground-water basin, it is likely that Dead Pike Lake receives ground-water flow on all sides as 
well. Other inlet channels may intermittently provide water to Dead Pike Lake during periods of high flow (spring snowmelt and intense precipitation). Outflow from Dead Pike Lake is through Little Lost Creek, which begins at the west end of the lake. When Little Lost Creek is flowing, the stage of Dead Pike Lake largely is controlled by the elevation of this outlet. In addition to ground-water flow, other hydrologic budget components for Dead Pike Lake include precipitation falling on the lake and water evaporating from the lake surface. In northern Wisconsin, annual precipitation exceeds evaporation by about 6 in/yr (Novitzki, 1982). Overland flow is assumed to be insignificant because infiltration rates of the sandy surface deposits are rarely exceeded by precipitation rates. Thus, overland flow is not included in the hydrologic conceptual model for the lake.

\section{CONSTRUCTION OF THE GFLOW MODEL}

Initial model development included estimating the elevation of the base of the shallow aquifer system, an areally uniform recharge rate, and a horizontal hydraulic conductivity. The base of the model approximates the bottom of the high-conductivity unconsolidated sediments (approximately 1,500 ft above sea level). The recharge rate and horizontal hydraulic conductivity, along with streambed resistance were considered calibration parameters, and thus were varied during model calibration. Recharge was set to $10.0 \mathrm{in} / \mathrm{yr}$ and horizontal hydraulic conductivity set to $100 \mathrm{ft} / \mathrm{d}$. These parameters are similar to those used by Hunt and others (1998) in the construction of a ground-water-flow model of the nearby Trout Lake area.

Based on the conceptual model, the location and elevation of far-field surface-water features were added (fig. 3). These features are distant rivers and lakes that are simulated with coarse linesinks and no resistance between the surface-water features and the groundwater system (that is, simulated as having a good hydraulic connection). The purpose of simulating the far field is to have the model explicitly define the regional ground-water-flow field near Dead Pike Lake and Powell Marsh (called the near field). The near field encompasses the features in the area of interest, as well as other nearby features that affect the hydrology of the lakes (fig. 3). Streambed sediment resistance in the near field initially was set equal to 0.3 day. Resistance in analytic element modeling is calculated by dividing the streambed sediment thickness by the vertical hydraulic conductivity. In this model, the value of 0.3 day corresponds to a 1-ft sediment thickness with a vertical hydraulic conductivity of $3.3 \mathrm{ft} / \mathrm{d}$, which is representative of a good connection between the ground-water and surface-water systems. The width of the stream was assigned according to stream order, and ranged from 10 to $50 \mathrm{ft}$.

Streams and lakes in the far field are not used for flux calibration, thus are simply modeled as individual linesinks. In near-field streams, a special more sophisticated type of linesink was used, called a "stream element" (Mitchell-Bruker and Haitjema, 1996). This element consists of linked linesinks that route water from high-elevation linesinks to low-elevation linesinks. During the routing through the stream network, the amount of water captured and lost by the stream is tabulated. This accounting allows the modeler to easily obtain a flux from any linesink in the stream network that includes flows from all the upstream linesinks. More importantly, the accounting also ensures that the amount of stream water lost to the ground-water system is restricted to the amount of water available (that is, captured from upgradient linesinks in the network). For streams where the headwaters are not included in the model domain, a headwater inflow term can be specified. This option was utilized for Sugarbush Creek, a steam with an appreciable headwater reach that is in the far field (fig. 3). Based on field measurements at the outlet of Sugarbush Lake, the amount of headwater inflow was set equal to $2.3 \mathrm{ft}^{3} / \mathrm{s}$, and was added to the stream element immediately downgradient of the lake (fig. 3). Lakes were simulated using linesinks with resistance. Dead Pike Lake was linked to the stream network with stream elements based on the methodology of Hunt and others (1998).

\section{MODEL CALIBRATION}

Calibration targets are measured field data, which are used to evaluate how well the model represents the actual ground-water system. The targets used here include both ground-water levels and streamflows (fig. 3). Ground-water levels for two wells (VI-761 and VI-653) were obtained from previously published reports (Patterson, 1989; Lidwin and Batten, 1996) and one well drilled for this study (A30). In addition to the ground-water levels, targets representing the lake levels for Sherman, Homestead, Pier, Sandy Beach and Little Trout Lakes also were used. The stage of these lakes is assumed to represent water-table elevation. Streamflow 


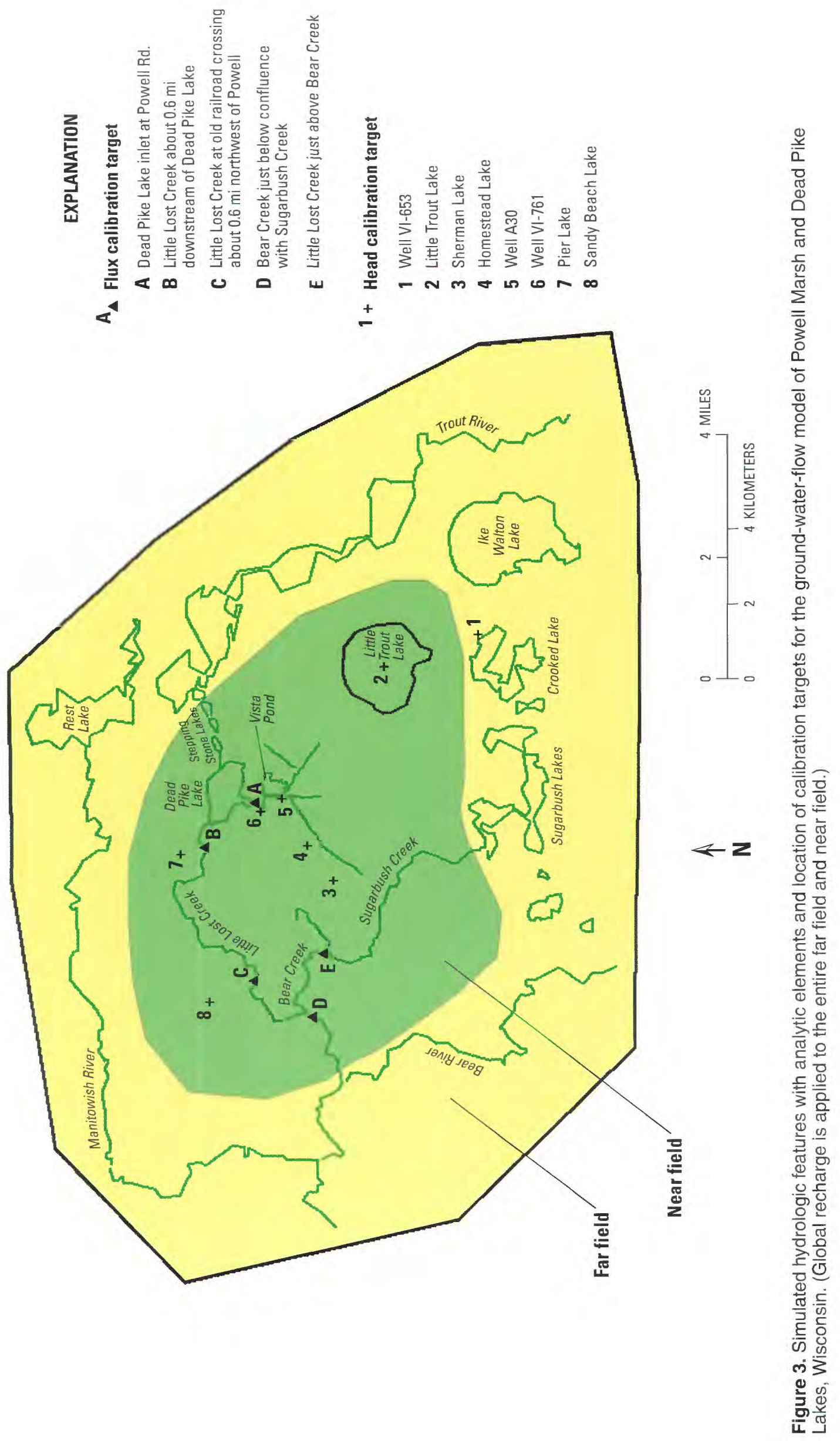




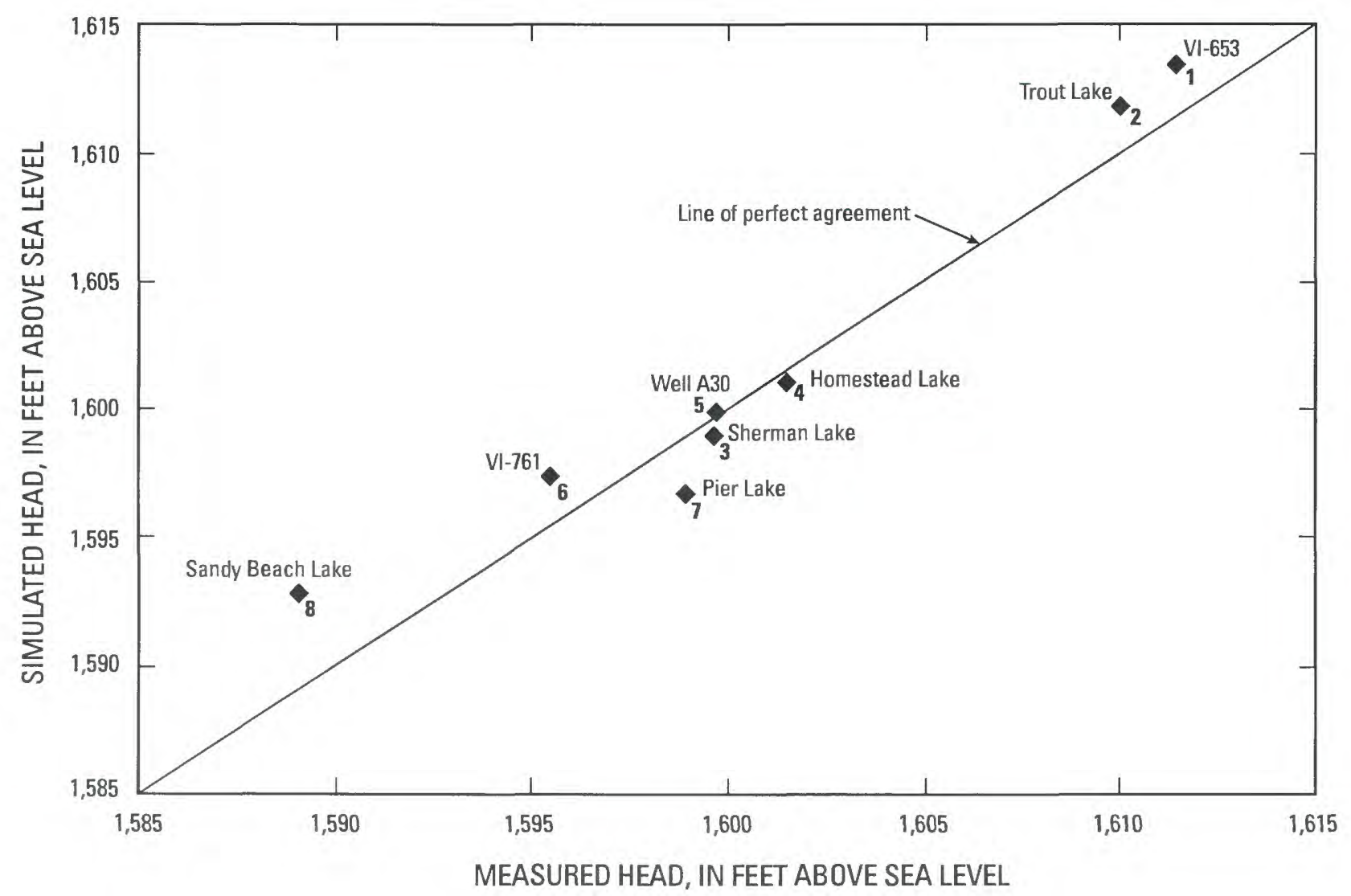

Figure 4. Measured and simulated head for the ground-water-flow model of Powell Marsh and Dead Pike Lake, Wisconsin. Location of head calibration targets are shown in figure 3 . Head measurements were made on June 14 and 15,2000 except for wells VI-761 and VI-653, which are from Batten and Lidwin, 1996.

or flux targets consisted of five sites in the near field where streamflow was measured during this study (fig. 3). These targets were used to constrain the simulated fluxes and associated regional recharge. The relation of the target to the model calibration is such that lower values of the streamflow target result in lower rates of recharge and lower corresponding horizontal hydraulic conductivity.

Using a recharge rate of $10 \mathrm{in} / \mathrm{yr}$, an aquifer hydraulic conductivity of $100 \mathrm{ft} / \mathrm{d}$, and a higher stream resistance for Bear and Sugarbush Creeks than other nearfield streams, a reasonable match between measured and simulated head and flux was obtained. A stream resistance of 10 , which results in a vertical hydraulic conductivity of $0.1 \mathrm{ft} / \mathrm{d}$ if the sediment thickness is $1 \mathrm{ft}$, was assigned to Bear and Sugarbush Creeks. All other near-field streams were assigned a resistance of 1 . The effect of increasing stream resistance was to reduce the amount of ground water discharging to Bear and Sugarbush Creeks and to increase water-table elevation in the vicinity of Powell Marsh. No data were collected to verify a high streambed resistance in Bear and Sugarbush
Creeks. However, field reconnaissance indicated that these streams are low gradient and contain large wetlands in their basins, which are typified by fine-grained streambeds and, therefore, yield high streambed resistance. Comparison between measured and simulated head is shown in figure 4. Calibration statistics based on eight head targets include the following differences between measured and simulated heads: a maximum of $3.8 \mathrm{ft}$, a minimum of $-2.2 \mathrm{ft}$, an average of $0.8 \mathrm{ft}$, a median of $1.0 \mathrm{ft}$, a mean absolute of $1.6 \mathrm{ft}$ and a root mean squared of $2.0 \mathrm{ft}$. These statistics are similar to those of other calibrated models (Hunt and others, 1996) and is considered a good steady-state model match.

The calibration to flux indicates that measured streamflow generally brackets simulated streamflow (fig. 5). Streamflow flux targets are based on only one measurement rather than the preferred method of having enough measurements over the range of high and low flows to determine flow duration (Krohelski and others, 2000). The calibration to flux is reasonable because most of the simulated flows are close to mea- 


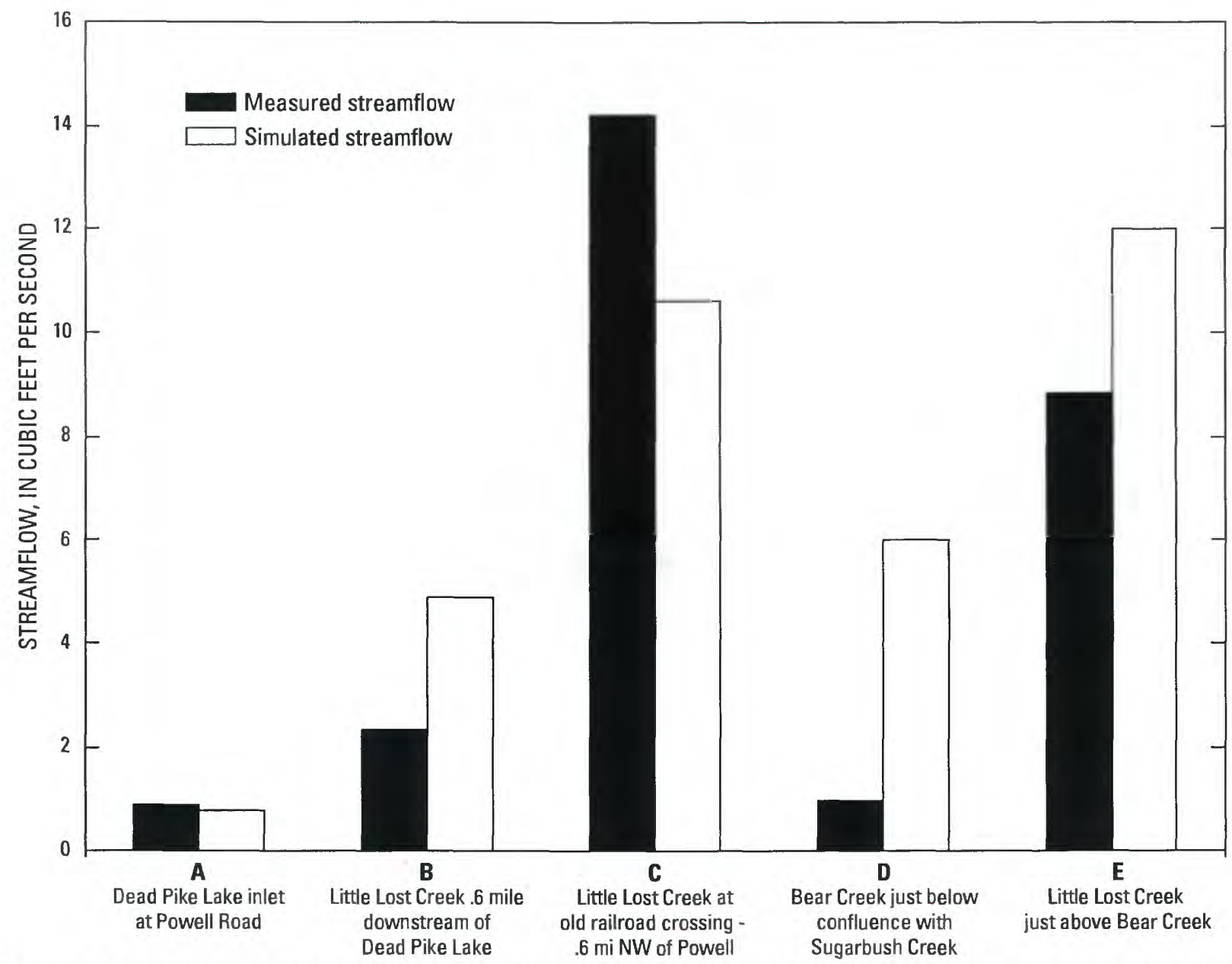

Figure 5. Measured and simulated flux (streamflow) for the ground-water-flow model of Powell Marsh and Dead Pike Lake, Wisconsin. Location of flux calibration targets are shown in figure 3 . Streamflow measurements were made on June 14 and 15, 2000.

sured flows with some higher and some lower. Some difficulty in measuring equilibrium streamflow conditions was encountered because of beaver activity; modifications to beaver dams are common and can cause reductions or increases in streamflow that may not be representative of the site under equilibrium or steadystate conditions in model simulation.

\section{MODEL RESULTS}

Ground water flows from high to low elevation and generally at right angles to contour lines on a map. Therefore, the contour map (fig. 6A) of calibrated model results indicates that the highest near-field watertable elevation occurs just south of Little Trout Lake and from this point ground-water flow is roughly radial. In the vicinity of Powell Marsh, ground water flows to the northwest and west. As indicated by the pathlines (red lines on figure 6A), ground water recharging on Powell Marsh likely will discharge to a ditch. For exam- ple, the pathline labeled " 1 " on figure 6A represents a simulated particle of water that is recharged at the water table and is simulated discharging to the ditch. Using an estimated porosity of 0.2 , the time of travel for this particle from the water table to the ditch is approximately 12 years. It also is interesting to note that in the vicinity of Dead Pike Lake, particles that are started at the water table on all sides of Dead Pike Lake eventually discharge to Dead Pike Lake (fig. 6A). The calibrated model indicates that Dead Pike Lake receives about $2.4 \mathrm{ft}^{3} / \mathrm{s}$ of ground-water inflow along with $1.0 \mathrm{ft}^{3} / \mathrm{s}$ of surface-water inflow from the south part of the Dead Pike Lake Basin (this part of the basin includes Powell Marsh) and about $0.9 \mathrm{ft}^{3} / \mathrm{s}$ of ground-water inflow from the north part for a total inflow to the lake of $4.3 \mathrm{ft}^{3} / \mathrm{s}$.

In order to approximate the effect of the Powell Marsh ditches and Vista Pond on the hydrology of Dead Pike Lake, the calibrated model was modified by removing the analytic elements that represent the ditches and pond. The same particle locations and con- 


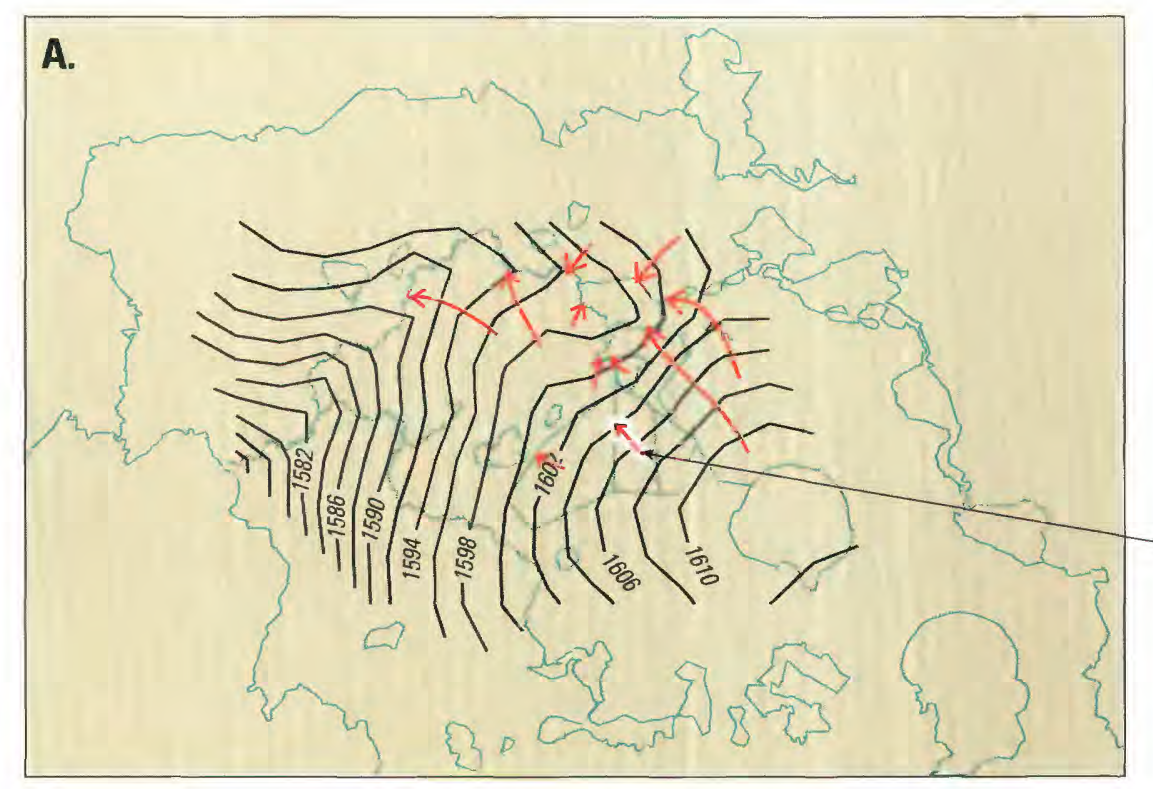

Pathline 1

EXPLANATION

$-1610-$ Simulated water-table contour, in feet above sea level-contour interval is $\mathbf{2}$ feet

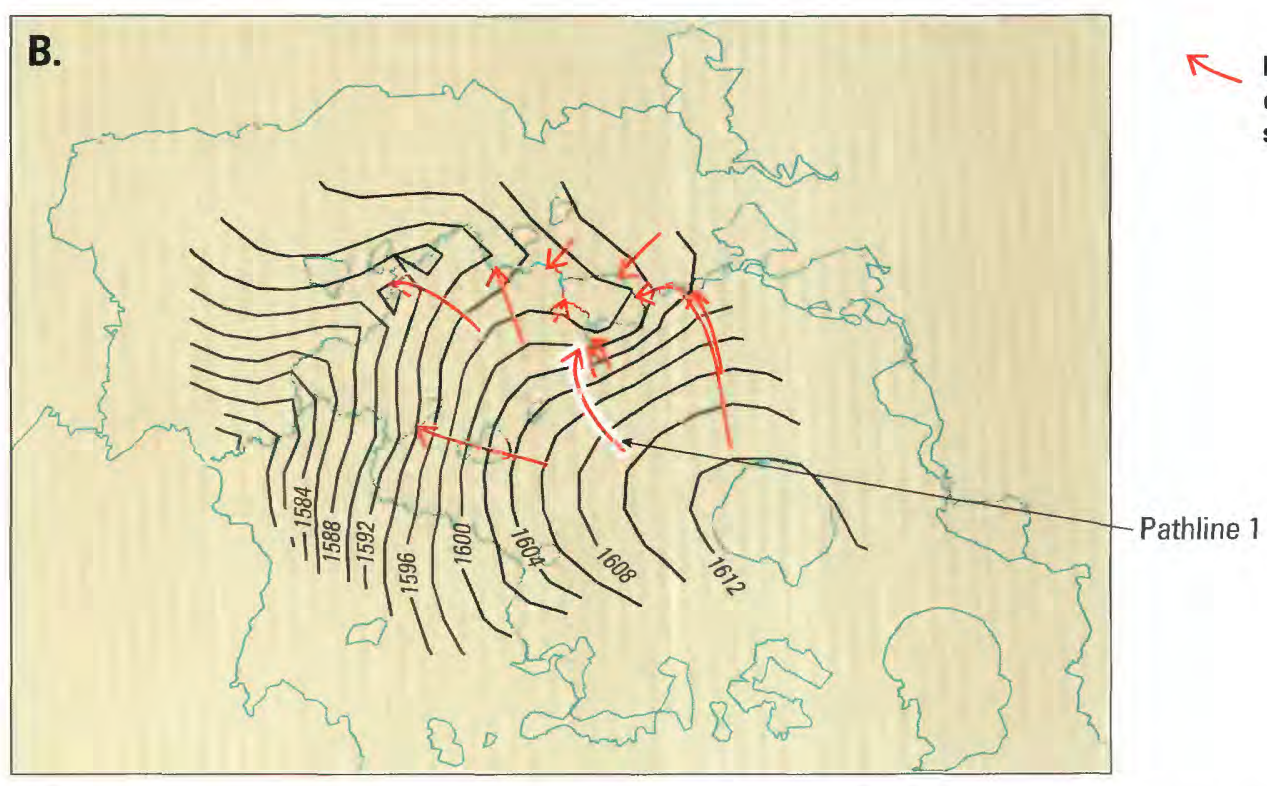

Figure 6. Simulated water-table elevation and selected path lines for (A) calibration and (B) without Powell Marsh structures (ditches and Vista Pond), Vilas County, Wisconsin.

tour interval used to present the calibrated model are presented for the case without the Powell Marsh features in figure 6B. Model results with the Powell Marsh features removed indicate a water-table elevation in the vicinity of Little Trout Lake would be about $2 \mathrm{ft}$ higher than the simulated conditions in the calibrated model. Although the shape of the contours is approximately the same as the simulation with the features, indicating that the general direction of ground-water flow is the about the same, the gradient as indicated by the spacing of the contours (compare figure 6A to 6B) in the vicinity of Powell Marsh is slightly steeper. The travel time from recharge to discharge of the pathline labeled " 1 " is much longer ( 36 years compared to 12 years) because the simulated pathline does not discharge to the ditch but to the inlet stream of Dead Pike Lake, a longer distance from the site where the pathline was started (recharged). The model simulation without the Powell Marsh features also indicates that the amount of water entering Dead Pike Lake is approximately the same as the simulation when the Powell Marsh features were included. Ground-water inflow from the south is $3.0 \mathrm{ft}^{3} / \mathrm{s}$ and $0.5 \mathrm{ft}^{3} / \mathrm{s}$ from the inlet stream as compared to $2.4 \mathrm{ft}^{3} / \mathrm{s}$ of ground-water flow from the south and 


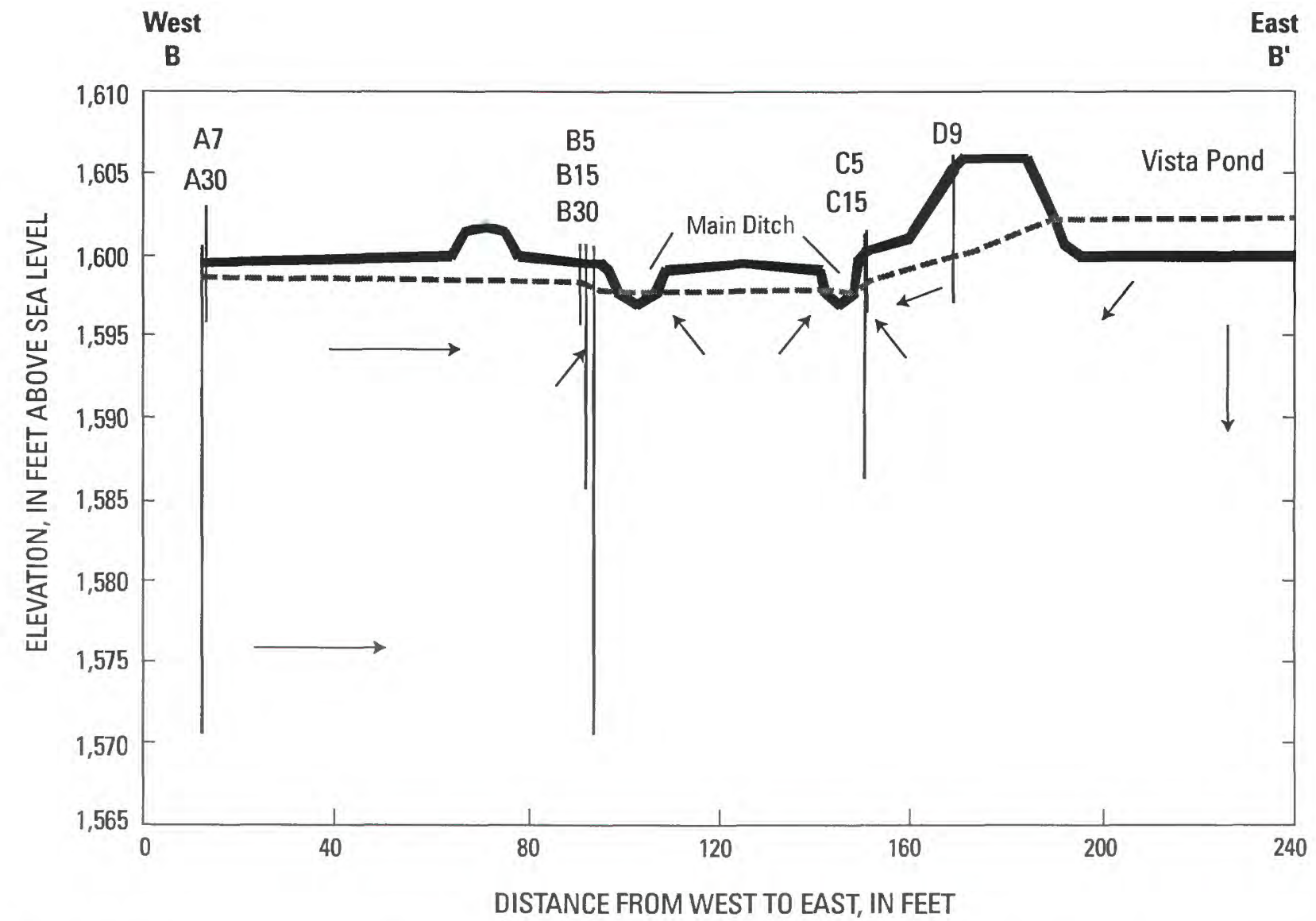

Figure 7. West to east section, B-B', showing the position of water table (dashed line) and direction of ground-water flow indicated by arrows, Vilas County, Wisconsin. Section trace is shown on figure 1. Piezometers locations are identified by letter ID and depth designation in feet.

$1.0 \mathrm{ft}^{3} / \mathrm{s}$ from the inlet stream in the calibrated model. As in the calibrated model case, there is $0.9 \mathrm{ft}^{3} / \mathrm{s}$ from the north part of the basin. Total inflow to Dead Pike Lake is $4.4 \mathrm{ft}^{3} / \mathrm{s}$ in the simulation without the Powell Marsh features, compared to $4.3 \mathrm{ft}^{3} / \mathrm{s}$ for the model that includes the Powell Marsh features. This result indicates that the Powell Marsh features do not change the overall lake water budget, but rather redistributes the water budget components slightly.

\section{RELATIONS BETWEEN THE GROUND- WATER AND SURFACE-WATER SYSTEMS}

Field data were collected during the study to determine the hydrologic relation between the ground- and surface-water systems and to determine the geochemical process of iron and manganese transport. Piezometers made of 1 -inch diameter PVC with 1 -ft-long number 10 screens were installed along section B-B' (fig. 1). The section is about $200 \mathrm{ft}$ long and was chosen to intersect Vista Pond and the Main Ditch, which is split into two channels along the section (fig. 7).

\section{Hydrogeology}

Piezometer nests are located at 4 sites along the section B-B' to determine vertical and horizontal gradients. The location of the piezometers in section and the direction of ground-water flow based on ground-water and surface-water level measurements are shown on figure 7 . The deepest piezometers are finished $30 \mathrm{ft}$ below land surface. A $12-\mathrm{ft}$ sediment core was obtained close to piezometer site "A". The core consisted of a 2 -ft peat layer underlain by medium to coarse sand. The surface elevation of Vista Pond and ground-water levels measured in the piezometer "D-9" indicate flow from Vista Pond to the west toward the ditches. The groundwater level in "D-9" was well below the level of Vista Pond but above levels in nest " $\mathrm{C}$ " indicating downward 


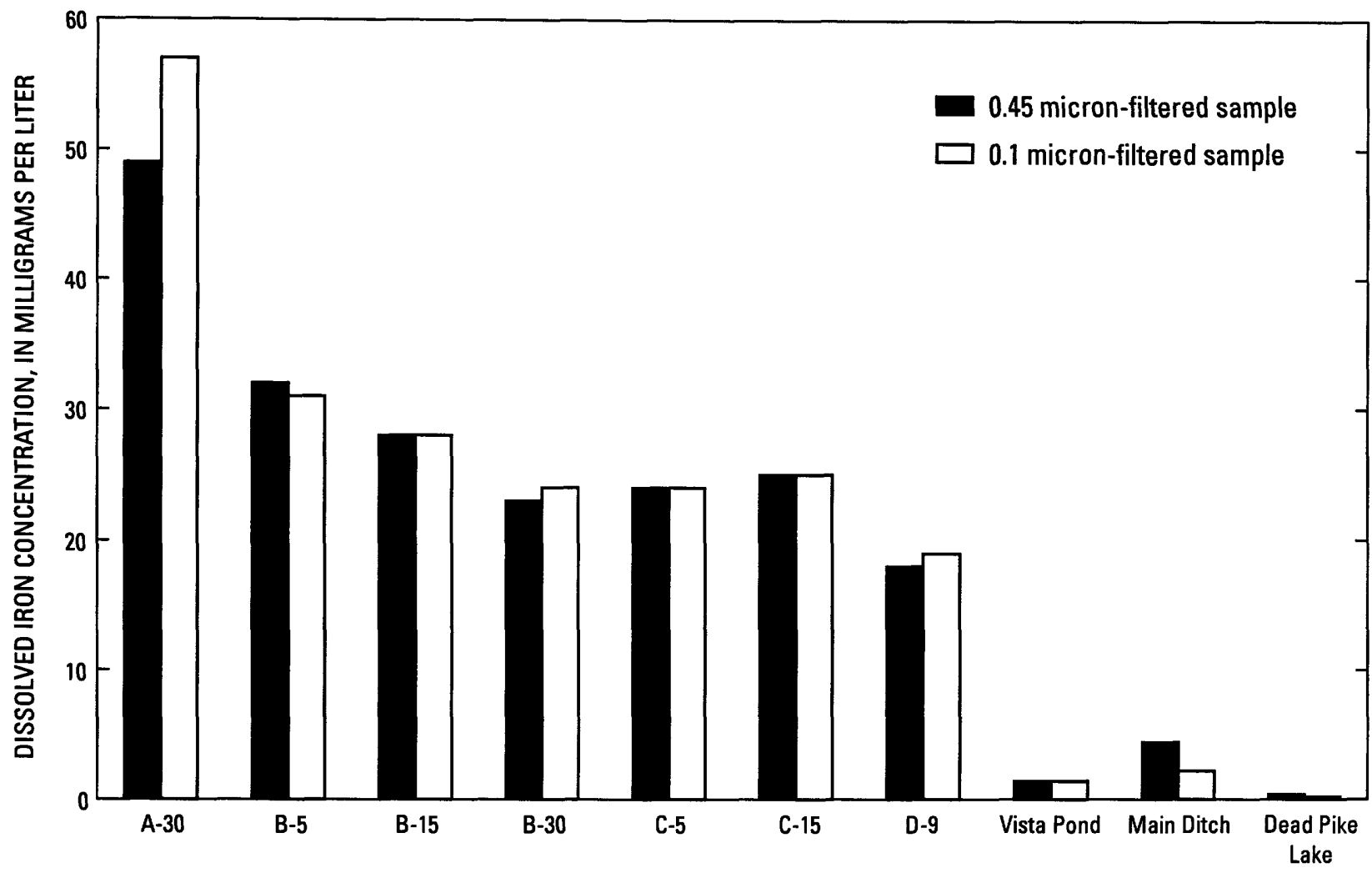

Figure 8. Comparison of iron concentrations in 0.45 micron-filtered water samples, Vilas County, Wisconsin. Location identifiers (for example, A-30) are those from the cross section shown in figure 7.

movement. Ground-water levels measured in nest "C" piezometers indicate upward movement and discharge into the eastern ditch. At nest " $A$ ", ground-water levels were identical in the "A-7" and "A-30" piezometers indicating only horizontal flow. Ground-water levels in piezometer nest " $\mathrm{B}$ " indicate horizontal movement from site " $A$ " to " $B$ " (west to east) and upward at "B" discharging to the western ditch.

\section{Geochemistry}

The form (dissolved and/or precipitated) and transport of iron and manganese in ground water is affected by environmental conditions, particularly in changes of oxidation or reduction. For brevity this discussion will focus on iron but it also applies to manganese. Reduction/oxidation state (or "redox") refers to the relative availability of electron donors or acceptors in aqueous systems (Stumm and Morgan, 1970). Systems with an appreciable concentration of "electron donors" are described as having reducing conditions with a negative Eh value; systems with an appreciable concentration of "electron acceptors" result in oxidizing conditions with a positive Eh value. Dissolved oxygen is an efficient electron acceptor; thus, the presence of dissolved oxygen is considered to be a strong indicator of oxidizing conditions. Generally, iron in a reduced state, $\mathrm{Fe}$ (II), is soluble and will travel along with ground water, but iron in an oxidized state, $\mathrm{Fe}$ (III), in the presence of oxygen may form a precipitate or oxyhydroxide floc; when in a floc form the iron is not transported with the water. Iron chemistry can be affected by additional complicating factors. For example, iron complexes can form with DOC (Hem, 1989). Fe (II) in complexes may be considerably more resistant to oxidation or the DOC can stabilize Fe (III), preventing or delaying the formation of iron floc. Iron solubility also is a function of $\mathrm{pH}$, the amount of hydrogen ion in solution, but because all waters on Powell Marsh sampled during the study were similar ( $\mathrm{pH}$ between 5.8 and 6.9, appendix 3), the discussion presented here will focus on the effects of redox and the presence or absence of oxygen.

To gain insight into the processes that lead to the formation of iron floc in the Powell Marsh ditch network, water samples were collected from both surface 


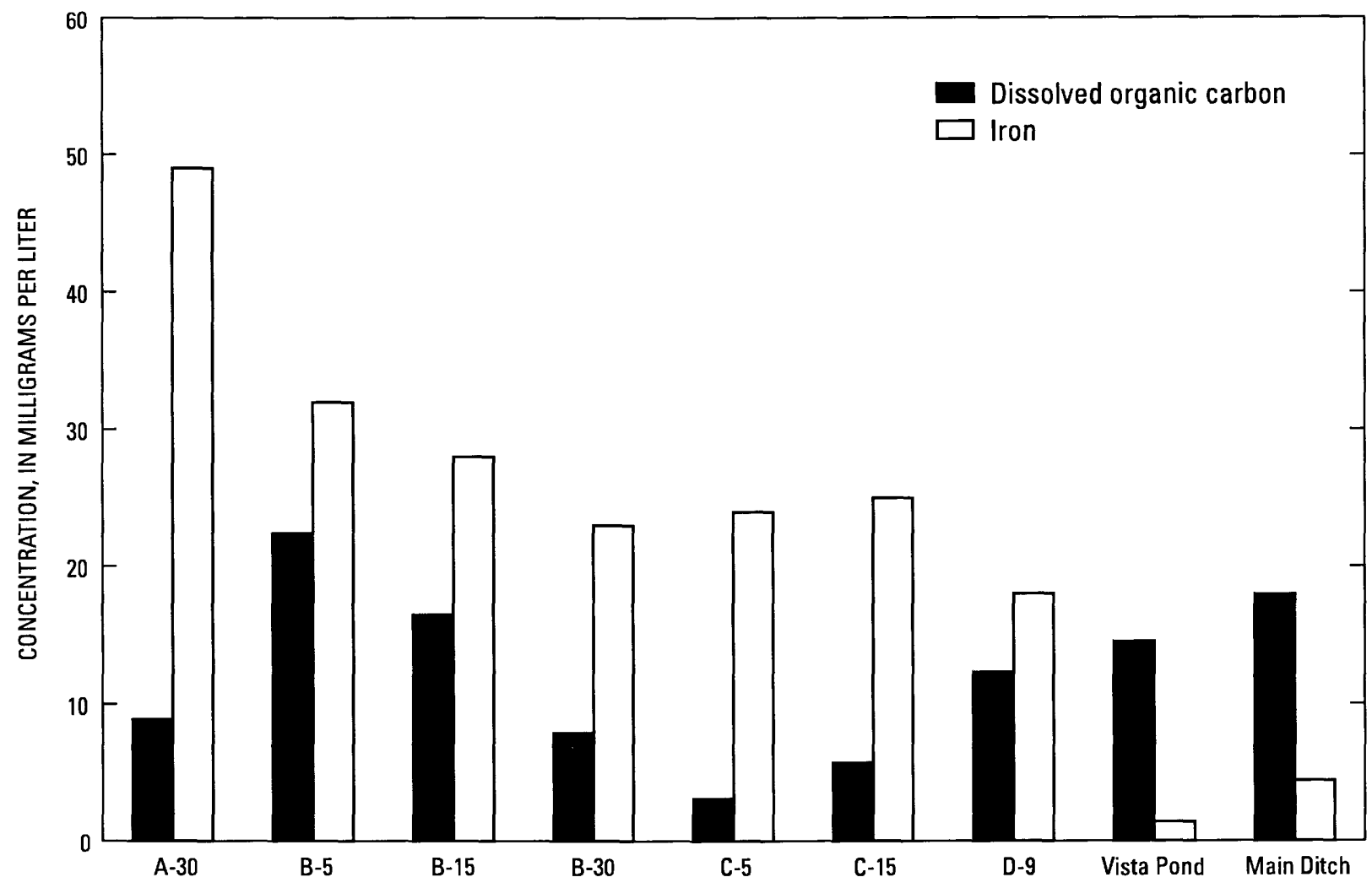

Figure 9. Comparison of dissolved organic carbon concentration to iron in 0.45 micron-filtered water samples, Vilas County, Wisconsin. Location identifiers (for example, A-30) are those from the cross section in figure 7.

and ground water. As previously discussed, the section B-B' is along a flow path that intersects typical Powell Marsh surface-water features (pond and ditch) and the ground-water system. Dissolved iron concentrations were found to be higher than what commonly is found in ground water in northern Wisconsin, a result of the high amounts of naturally occurring iron present in the aquifer. Moreover, the iron measured in the ground water was over ten times higher than concentrations measured in surface water, reflecting the change in the solubility of the iron when exposed to the dissolved oxygen present in the surface water.

The analyses gave near identical iron concentrations for the 0.45 and 0.1 micron-filtered samples (fig. 8) indicating that the iron nominally is "dissolved" or perhaps present as iron (III)-DOC complexes with less than 0.1-micron sizes. The latter transport mechanism has been noted in central Vilas County where high concentrations of iron in ground water were attributable to iron (III)-DOC complexes smaller than 0.1-micron (Krabbenhoft, 1984). The relative importance of DOCfacilitated transport of iron in ground water is not well understood because of the lack of information regarding the DOC quality and the low correlation between DOC and iron concentrations (fig. 9). Although a strong correlation may be expected between high concentrations of iron and DOC if organic molecules play an important factor, it is possible that other factors rather than DOC concentrations limit iron transport. Regardless of the exact iron transport mechanism, it is important to note that water sampling demonstrated that high iron concentrations transported by ground water are precipitated as iron floc when the ground water is discharged into a surface-water body. Thus, it appears that dissolved oxygen in the surface water is able to combine with the iron-whether dissolved or carried by DOC colloidsand form the oxyhydroxide floc.

Iron transport can be explained from a regional flow system perspective. The capacity of ground water to transport iron is related to the redox potential of the ground-water system. The redox potential, in turn, is related to the location in the ground-water-flow system. Infiltrating water from the land surface carries oxygen obtained from the atmosphere; this dissolved oxygen is carried with the infiltrating water as it recharges the ground-water system. The presence of dissolved oxy- 


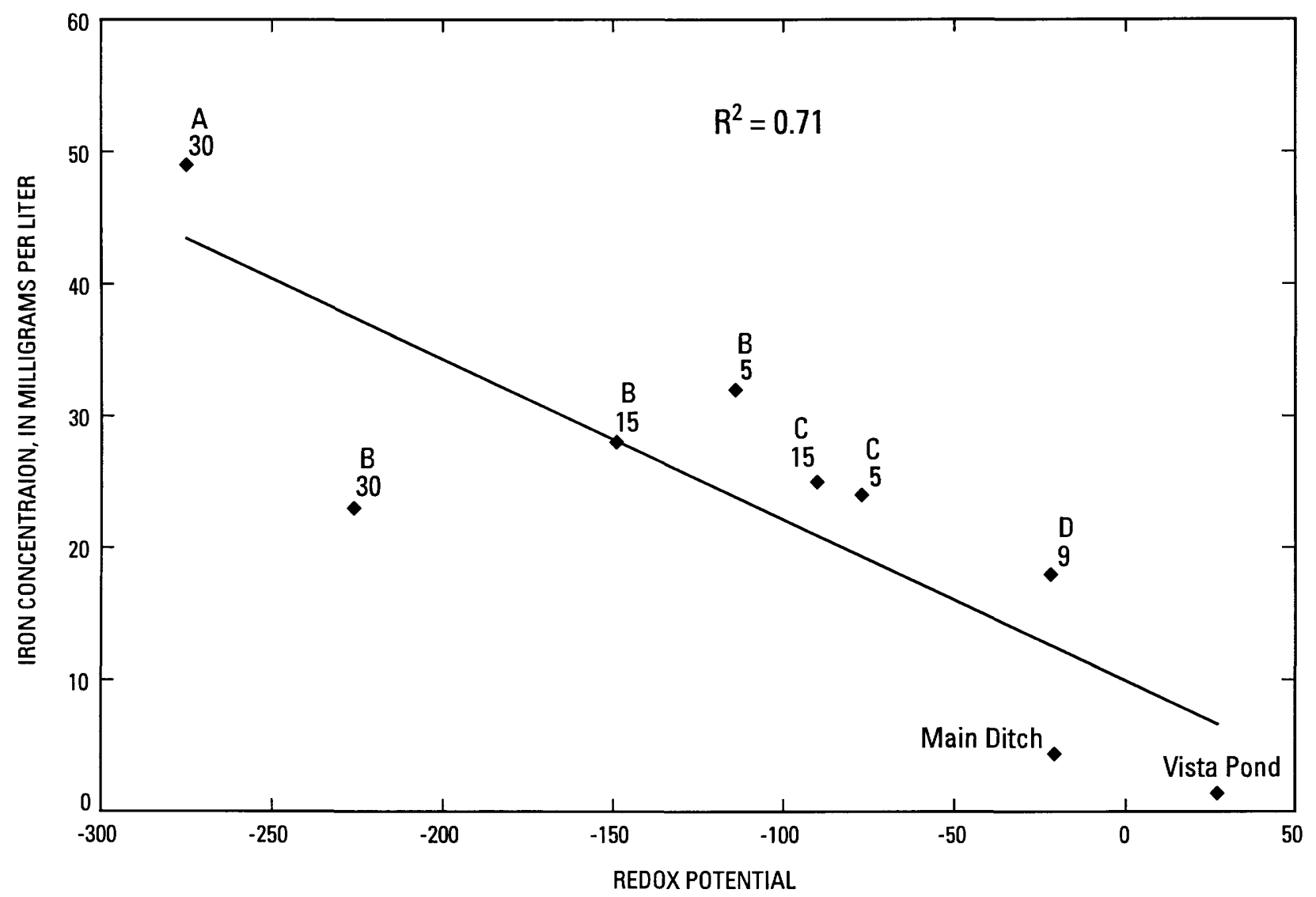

Figure 10. Relation of iron concentration in 0.45 micron-filtered samples to redox potential, Vilas County, Wisconsin. Location identifiers (for example $(A-30)$ are those form the cross section shown in figure 7 . [ $R^{2}$, coefficient of determination, is an indicator that ranges from 0 to 1 and reveals how closely the estimated values for the trendline correspond to the actual data. A trendline is most reliable when its $R^{2}$ is at or near 1.]

gen in the recently recharged water causes the water to have a high oxidation potential; thus, iron is in the oxidized form and is not soluble. Along its subsurface flow path, the ground water encounters conditions that can consume the dissolved oxygen, most commonly microbial communities and organic matter (Freeze and Cherry, 1979). Thus, water that has traveled farther, and has had greater exposure to these conditions will contain less dissolved oxygen. Given enough distance the dissolved oxygen will be completely consumed and the ground water becomes reducing. When the ground water becomes sufficiently reducing, iron containing minerals in the aquifer can dissolve and the iron can be transported by the ground-water system.

As the ground water flows from the recharge area to the discharge area, additional water is added to the top of the saturated zone as the aquifer receives recharge from infiltrating water. Thus, deeper water (deeper than the infiltrating water) will have traveled further than shallower water. This result is demon- strated by the field data collected in this study; water samples from deeper piezometers represent longer ground-water-flow paths with more reducing conditions, and more dissolved iron (fig. 10). Water samples from shallower wells represent shorter flow paths with more oxidizing conditions, and lower concentrations of dissolved iron (fig. 10). Surface waters in the ditch and Vista Pool has a constant source of oxygen from the atmosphere, and thus, are always oxidizing. These sites have low dissolved iron, but higher amounts of particulate iron floc representing the change of iron from the dissolved to solid phase. Results from these surfacewater samples can be considered to represent the end of the ground-water-flow path.

\section{SUMMARY AND CONCLUSIONS}

There is concern that iron floc from Powell Marsh ditches is damaging the aesthetic quality of Dead Pike Lake in western Vilas County, Wis. A study was initi- 
ated by the U.S. Geological Survey, in cooperation with Wisconsin Department of Natural Resources to evaluate the effect of Powell Marsh on the hydrology of Dead Pike Lake and to determine the source of iron floc and the potential for its transport from Powell Marsh to Dead Pike Lake.

A calibrated analytic element ground-water-flow model indicates ground water generally flowing from Powell Marsh to the northwest toward Dead Pike Lake and west toward Little Lost Creek. Simulation results indicate that, from the south part of its watershed, Dead Pike Lake receives about $2.4 \mathrm{ft}^{3} / \mathrm{s}$ of ground water and $1 \mathrm{ft}^{3} / \mathrm{s}$ of surface water. If the Powell Marsh structures were removed, Dead Pike Lake would receive about $3 \mathrm{ft}^{3} / \mathrm{s}$ of ground-water flow and $0.5 \mathrm{ft}^{3} / \mathrm{s}$ of surface water. These results show that Powell Marsh hydrologic structures change the distribution of the water budget components but not the overall water budget for Dead Pike Lake.

Water levels measured along a west to east flow path indicate that water moves from Vista Pond and the marsh and discharges to ditches. Analyses of ground and surface waters along the flow path indicate that dissolved iron is relatively high in ground water and low in surface water (the ditches and Vista Pond). Naturally occurring dissolved iron in ground water derived from surficial deposits is the source of iron floc in the Powell Marsh ditches and is coincident with iron floc observations. Iron and manganese precipitate and form a floc when the ground water discharges to the ditches. The transport and form of iron and manganese in the water of the Dead Pike Lake area can be explained by oxidation/reduction. If ditches were removed, floc forming in the ditches would no longer be available for transport because the environment that is suitable for floc formation would be removed. However, it is likely that the floc formation may be redirected to the near-shore environment in Dead Pike Lake where ground water discharges.

\section{REFERENCES}

Attig, J.W., 1985, Pleistocene Geology of Vilas County, Wisconsin: Wisconsin Geological and Natural History Survey Information Circular 50, $32 \mathrm{p}$.

Batten, W.G., and Lidwin, R.A., 1996, Water Resources of the Lac Du Flambeau Indian Reservation, Wisconsin,
1981-86: U.S. Geological Survey Water-Resources Investigation Report 94-4025, 42 p.

Bradbury, K.R., and Muldoon, M.A., 1990, Hydraulic conductivity determinations in unlithified glacial and fluvial materials, In Ground Water and vadose Zone Monitoring: American Society for Testing and materials, ASTM STP 1050, Philadelphia, p. 138-151

Freeze, A.F., and Cherry, J.A., 1979, Groundwater: Prentice Hall Inc., Englewood Cliffs, New Jersey, 604 p.

Haitjema, H.M., 1995, Analytic element modeling of groundwater flow: Academic Press, San Diego, CA, 394 p.

Hem, J.D., 1989, Study and interpretation of the chemical characteristics of natural water: U.S. Geological Survey Water Supply Paper 2254, third edition, $263 \mathrm{p}$.

Hunt, R.J., and Krohelski, J.T., 1996, The application of an analytic element model to investigate groundwater-lake interactions at Pretty Lake, Wisconsin: Journal of Lake and Reservoir Management, v. 12, no. 4, p. 487-495.

Hunt, R.J., Anderson, M.P., and Kelson, V.A., 1998, Improving a complex finite-difference ground water flow model through the use of an analytic element screening model: Ground Water, v. 36, no. 6, p. 1011-1017.

Krabbenhoft, D.P. 1984, Hydrologic and geochemical controls of freshwater ferromanganese deposit formation at Trout Lake, Vilas County, Wisconsin: MS thesis, University of Wisconsin-Madison, $137 \mathrm{p}$.

Krohelski, J.T., Bradbury, K.R., Hunt, R.J., and Swanson, S.K., 2000, Numerical simulation of groundwater flow in Dane County, Wisconsin: Wisconsin Geological and Natural History Survey Bulletin 98, 31 p.

Mitchell-Bruker, S., and Haitjema, H., 1996, Modeling steady state conjunctive groundwater and surface water flow with analytic elements: Water Resources Research, v. 32, no. 9, p. 2725-2732.

Novitzki, R.P., 1982, Hydrology of Wisconsin Wetlands: Wisconsin Geological and Natural History Survey Information Circular Number 40, 22 p.

Patterson, G.L., 1989, Water Resources of Vilas County, Wisconsin: Wisconsin Geological and Natural History Survey Miscellaneous Paper 89-1, 32 p.

Strack, O.D.L., 1989, Groundwater Mechanics: Englewood Cliffs, New Jersey, Prentice-Hall, 732 p.

Stumm, W., and Morgan, J.J., 1970, Aquatic Chemistry, an introduction emphasizing chemical equilibria in natural waters: Wiley-Interscience, John Wiley and Sons Inc., New York, $583 \mathrm{p}$.

Wisconsin Department of Natural Resources, 1995, Wisconsin Lakes, Wisconsin Department of Natural Resources PUB-FM-800 95 REV, 182 p. 


\section{APPENDIXES 1-3}


Appendix 1. Coordinates and elevations of sites measured by Global Positioning System

\section{TABLES}

A1. Location of lake and stream-elevation measurements, Vilas County, Wisconsin ............................................. 17

A2. Locations of piezometers and Vista Pond along section B-B', Vilas County, Wisconsin ................................... 18

A3. Locations of water-level measurements upstream and downstream of Powell Marsh structures, Vilas County, Wisconsin 


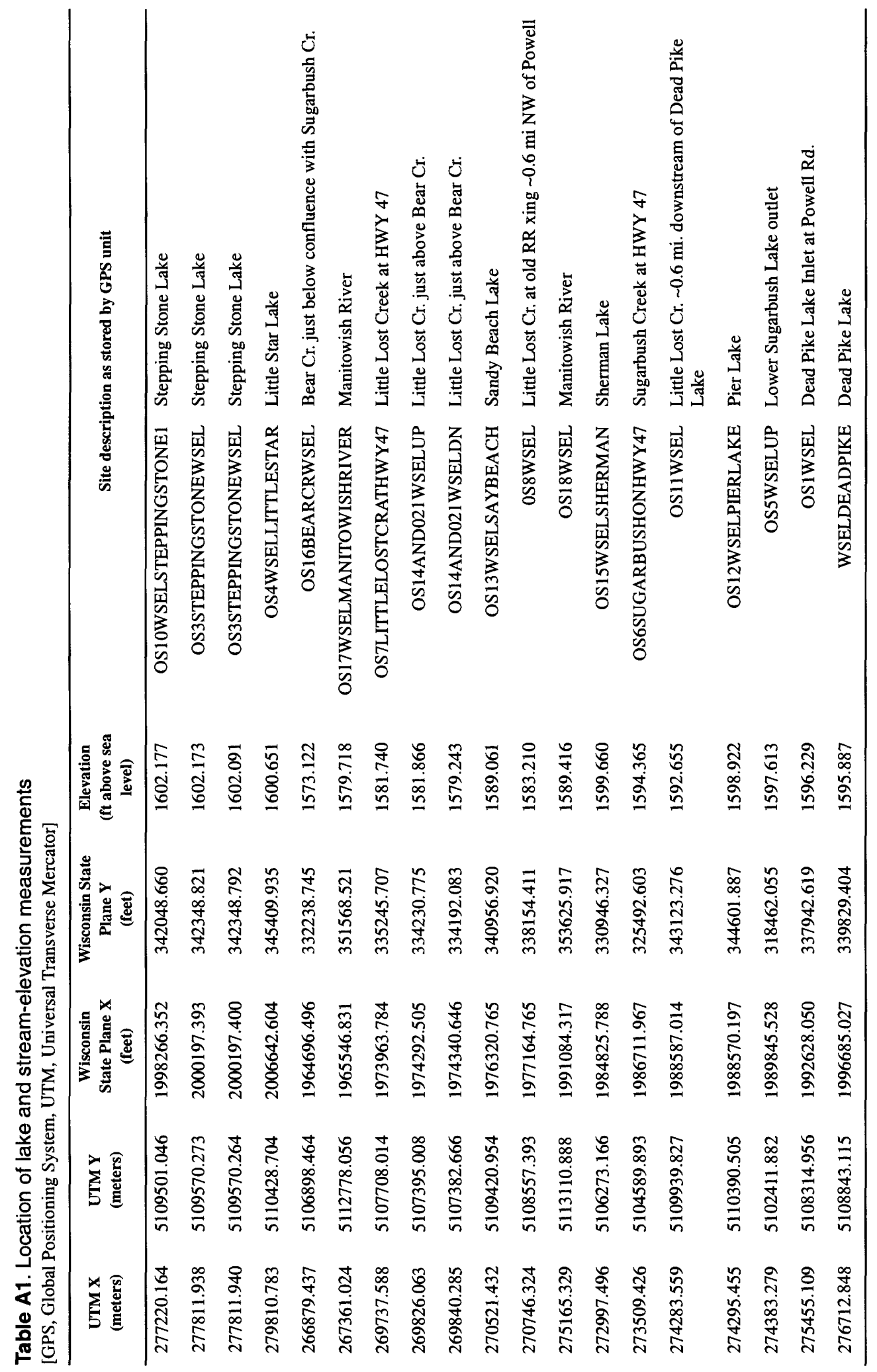


Table A2. Locations of piezometers and Vista Pond along section B-B' [GPS, Global Positioning System; UTM, Universal Transverse Mercator]

\begin{tabular}{|c|c|c|c|c|c|c|}
\hline UTM X & UTM Y & $\begin{array}{l}\text { Wisconsin State } \\
\text { Plane X }\end{array}$ & $\begin{array}{l}\text { Wisconsin State } \\
\text { Plane Y }\end{array}$ & $\begin{array}{c}\text { Elevation } \\
\text { (ft above sea }\end{array}$ & \multicolumn{2}{|c|}{ Site description as stored by GPS unlt } \\
\hline 275792.215 & 5107873.055 & 1993787.653 & 336535.960 & 1600.547 & WELLA30 & Piezometer A-30 \\
\hline 275816.789 & 5107864.372 & 1993869.272 & 336510.543 & 1600.686 & WELLB5 & Piezometer B-5 \\
\hline 275817.327 & 5107864.364 & 1993871.034 & 336510.583 & 1600.686 & WELLB15 & Piezometer B-15 \\
\hline 275817.993 & 5107864.321 & 1993873.223 & 336510.523 & 1600.463 & WELLB30 & Piezometer B-30 \\
\hline 275831.288 & 5107862.842 & 1993916.981 & 336507.321 & 1597.751 & VISTAPONDDNWSEL & Vista Pond \\
\hline 275834.537 & 5107864.213 & 1993927.461 & 336512.219 & 1601.305 & WELC15 & Piezometer C-15 \\
\hline 275834.585 & 5107863.701 & 1993927.681 & 336510.544 & 1601.546 & WELLC5 & Piezometer C-5 \\
\hline 275840.267 & 5107860.934 & 1993946.646 & 336502.178 & 1606.114 & WELLD9 & Piezometer D-9 \\
\hline 275847.110 & 5107863.396 & 1993968.771 & 336511.096 & 1602.154 & VISTAPONDWSEL & Vista Pond \\
\hline
\end{tabular}

Table A3. Locations of water level measurements upstream and downstream of Powell Marsh structures [GPS, Global Positioning System; UTM, Universal Transverse Mecator]

\begin{tabular}{|c|c|c|c|c|c|}
\hline UTM X (meters) & UTM Y (meters) & $\begin{array}{l}\text { Wisconsin State } \\
\text { Plane X (feet) }\end{array}$ & $\begin{array}{l}\text { Wiscons in State } \\
\text { Plane Y (feet) }\end{array}$ & $\begin{array}{c}\text { Elevation } \\
\text { (ft above sea ievei) }\end{array}$ & $\begin{array}{c}\text { Site description as stored } \\
\text { by GPS unit }\end{array}$ \\
\hline 275834.007 & 5108254.793 & 1993877.372 & 337792.325 & 1602.170 & 008WSELUP \\
\hline 275823.753 & 5107796.328 & 1993900.519 & 336288.382 & 1597.794 & 009WSELDN \\
\hline 275826.451 & 5107784.989 & 1993910.765 & 336251.551 & 1603.271 & 009WSELUP \\
\hline 275816.945 & 5107625.388 & 1993899.365 & 335727.262 & 1603.234 & 010WSELUP \\
\hline 275807.278 & 5107622.181 & 1993868.080 & 335715.554 & 1602.212 & 010WSELDN \\
\hline 275802.468 & 5106643.838 & 1993973.412 & 332508.324 & 1603.206 & 011WSELUP \\
\hline 275803.275 & 5106651.756 & 1993975.077 & 332534.376 & 1603.255 & 011WSELDN \\
\hline 276577.150 & 5107279.865 & 1996433.790 & 334688.851 & 1604.861 & 012WSELDN \\
\hline 276577.602 & 5107273.447 & 1996436.066 & 334667.869 & 1605.266 & 012WSELUP \\
\hline 276488.424 & 5107352.898 & 1996133.939 & 334917.246 & 1603.182 & 013WSELDN \\
\hline 276492.231 & 5107334.801 & 1996148.658 & 334858.402 & 1603.538 & 013WSELDNWEST \\
\hline 276495.515 & 5107348.918 & 1996157.675 & 334905.079 & 1604.891 & 013WSELUP \\
\hline 276570.225 & 5107391.225 & 1996397.307 & 335052.990 & 1604.818 & 014WSELDN \\
\hline 276576.253 & 5107399.411 & 1996416.050 & 335080.568 & 1605.555 & 014WSELUP \\
\hline 277347.164 & 5106801.698 & 1999016.789 & 333216.883 & 1605.954 & 015WSELDN \\
\hline 277348.531 & 5106793.997 & 1999022.224 & 333191.811 & 1607.655 & 015WSELUP \\
\hline 277281.731 & 5106788.424 & 1998803.967 & 333165.277 & 1604.812 & 016WSELDN \\
\hline 277286.445 & 5106783.990 & 1998819.966 & 333151.328 & 1607.526 & 016WSELUP \\
\hline 277244.408 & 5108333.815 & 1998490.332 & 338225.898 & 1603.115 & 017WSELDN \\
\hline 277252.425 & 5108328.563 & 1998517.260 & 338209.678 & 1605.534 & 017WSELUP \\
\hline 274679.631 & 5106866.575 & 1990265.647 & 333099.424 & 1598.830 & 018WSELDN \\
\hline 274687.414 & 5106875.531 & 1990290.046 & 333129.740 & 1602.278 & 018WSELUP \\
\hline 275820.763 & 5108252.980 & 1993834.188 & 337784.741 & 1597.091 & WSELDNDAMATSTRUCT \\
\hline
\end{tabular}




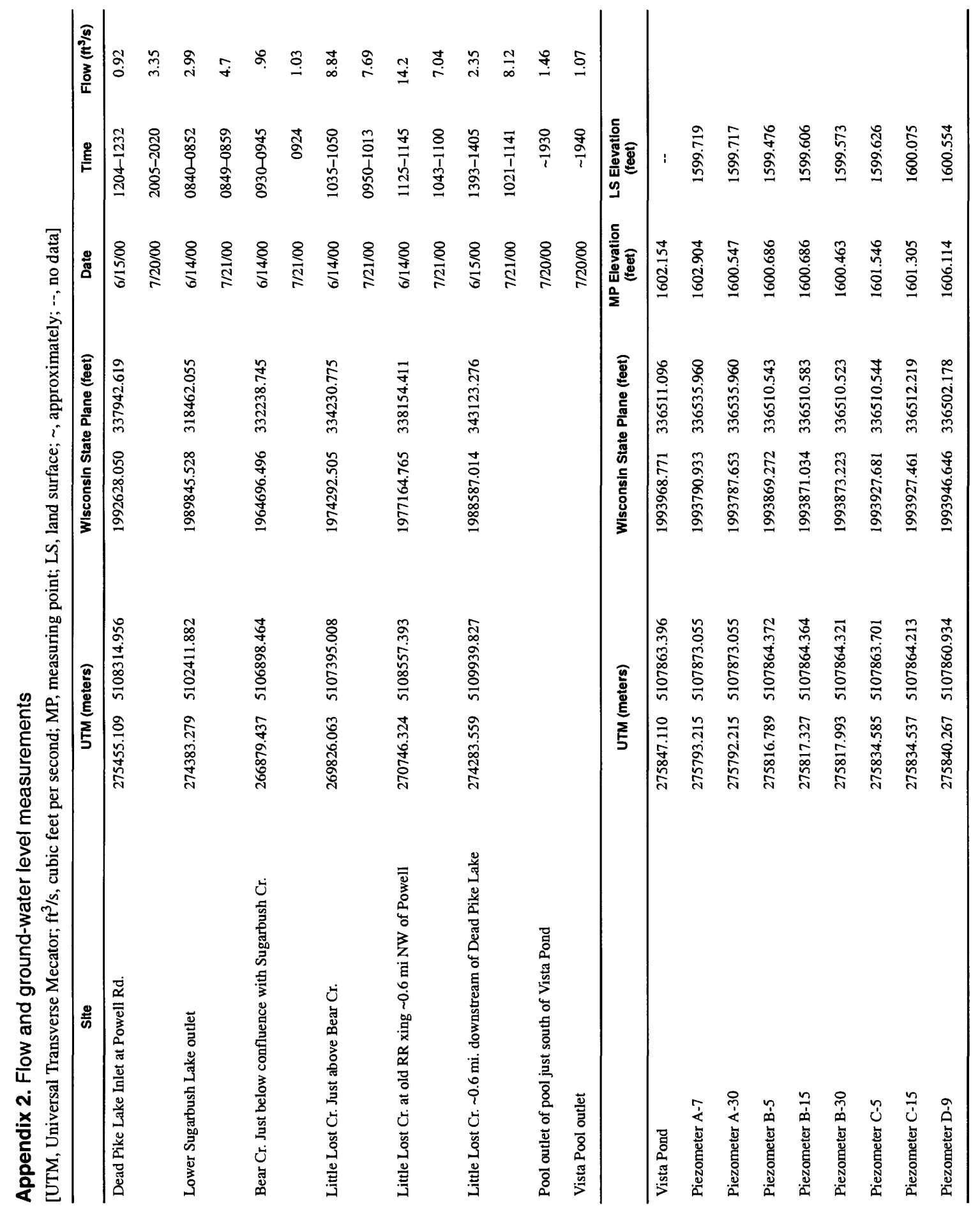


Appendix 3. Powell Marsh-Dead Pike Lake water analyses along section B-B'

[mg/L, milligrams per liter; ${ }^{\circ} \mathrm{C}$, degrees Celsius; organic $\mathrm{C}$, organic carbon; Mn, manganese; Fe, iron; --, no data]

\begin{tabular}{|c|c|c|c|c|c|c|c|c|c|c|}
\hline Site & Date & $\begin{array}{l}\text { Sample } \\
\text { treatment }\end{array}$ & $\begin{array}{c}\text { Organic C } \\
\mathrm{mg} / \mathrm{L}\end{array}$ & $\begin{array}{c}\text { Mn } \\
\mathrm{mg} / \mathrm{L}\end{array}$ & $\begin{array}{c}\mathrm{Fe} \\
\mathrm{mg} / \mathrm{L}\end{array}$ & $\begin{array}{c}\text { Temperature } \\
{ }^{\circ} \mathrm{C}\end{array}$ & $\begin{array}{c}\text { Specific } \\
\text { conductance }\end{array}$ & $\begin{array}{c}\text { Dissolved } \\
\text { oxygen } \\
\text { mg/L }\end{array}$ & pH & Redox \\
\hline \multirow[t]{3}{*}{ Piezometer A-30 } & $6 / 14 / 00$ & Raw water & 9.21 & 0.93 & 58 & 7.4 & 41 & 0.17 & 6.8 & -275 \\
\hline & & 0.45 micron & 8.88 & .85 & 49 & & & & & \\
\hline & & 0.1 micron & 8.62 & .95 & 57 & & & & & \\
\hline \multirow[t]{3}{*}{ Piezometer B-5 } & $6 / 15 / 00$ & Raw water & 23.39 & .43 & 33 & 10.45 & 24 & .2 & 6.2 & -114 \\
\hline & & 0.45 micron & 22.43 & .44 & 32 & & & & & \\
\hline & & 0.1 micron & 24.94 & .43 & 31 & & & & & \\
\hline \multirow[t]{3}{*}{ Piezometer B-15 } & $6 / 15 / 00$ & Raw water & 16.37 & .59 & 29 & 9.15 & 26 & .19 & 6.5 & -149 \\
\hline & & 0.45 micron & 16.49 & .61 & 28 & & & & & \\
\hline & & 0.1 micron & 15.91 & .61 & 28 & & & & & \\
\hline \multirow[t]{3}{*}{ Piezometer B-30 } & $6 / 14 / 00$ & Raw water & 8.56 & 1.2 & 61 & 9.83 & 40 & .2 & 6.9 & -226 \\
\hline & & 0.45 micron & 7.89 & .94 & 23 & & & & & \\
\hline & & 0.1 micron & 8.74 & .95 & 24 & & & & & \\
\hline \multirow[t]{3}{*}{ Piezometer C-5 } & $6 / 15 / 00$ & Raw water & 3.25 & .2 & 26 & 12.36 & 13 & .29 & 6.2 & -77 \\
\hline & & 0.45 micron & 3.12 & .2 & 24 & & & & & \\
\hline & & 0.1 micron & 3.44 & .19 & 23 & & & & & \\
\hline \multirow[t]{3}{*}{ Piezometer C-15 } & $6 / 15 / 00$ & Raw water & 8.98 & .31 & 27 & 11.3 & 17 & .22 & 6.2 & -90 \\
\hline & & 0.45 micron & 5.72 & .3 & 25 & & & & & \\
\hline & & 0.1 micron & 5.26 & .3 & 25 & & & & & \\
\hline \multirow[t]{3}{*}{ Piezometer D-9 } & $6 / 15 / 00$ & Raw water & 9.79 & .19 & 19 & 12.28 & 11 & .24 & 5.8 & -22 \\
\hline & & 0.45 micron & 12.33 & .19 & 18 & & & & & \\
\hline & & 0.1 micron & 11.45 & .2 & 19 & & & & & \\
\hline \multirow[t]{3}{*}{ Vista Pool } & $6 / 15 / 00$ & Raw water & 13.38 & .01 & 2.4 & 17.5 & 21 & 7.94 & 6 & 27 \\
\hline & & 0.45 micron & 14.55 & .01 & 1.4 & & & & & \\
\hline & & 0.1 micron & 18.55 & .01 & .71 & & & & & \\
\hline \multirow[t]{3}{*}{ Main Ditch } & $6 / 15 / 00$ & Raw water & 17.85 & .07 & 10 & 17.23 & 80 & 6.35 & 6 & -21 \\
\hline & & 0.45 micron & 17.97 & .06 & 4.4 & & & & & \\
\hline & & 0.1 micron & 14.56 & .05 & 2.2 & & & & & \\
\hline \multirow[t]{3}{*}{ Dead Pike Lake } & $7 / 20 / 00$ & Raw water & & .02 & .98 & 22.6 & 76 & 8.82 & 7.3 & -- \\
\hline & & 0.45 micron & & .00 & 37 & & & & & \\
\hline & & 0.1 micron & & .00 & .2 & & & & & \\
\hline
\end{tabular}



